\title{
FLOWERING PHENOLOGY OF SELECTED LINDEN (TILIA L.) TAXA IN RELATION TO POLLEN SEASONS
}

\author{
Agnieszka Dąbrowska1* \\ Krystyna Piotrowska-Weryszko² \\ Elżbieta Weryszko-Chmielewska ${ }^{3}$ \\ Ryszard Sawicki ${ }^{1}$ \\ 1 Botanical Garden, Maria Curie-Skłodowska University, 3 Sławinkowska Street, \\ 20-810 Lublin, Poland \\ 2Department of General Ecology, Lublin University of Life Sciences, \\ 58 Leszczyńskiego Street, 20-950 Lublin, Poland \\ 3Department of Botany, Lublin University of Life Sciences, 15 Akademicka Street, \\ 20-950 Lublin, Poland \\ * corresponding author: agnieszka.dabrowska@poczta.umcs.lublin.pl \\ Received: 21 June 2016; accepted: 28 October 2016
}

Abstract

All lindens provide Apidae insects with nectar, pollen, and honeydew. Lindens are important melliferous trees in Poland. The first purpose of the study was to carry out phenological observations of the flowering in ten linden taxa. The second aim was to analyse the content of linden pollen grains in the air of Lublin. A correlation between the parameters of the pollen season and meteorological factors was also determined. This study was conducted in the city of Lublin located in the central-eastern part of Poland. The flowering phenophases were analysed, using the method developed by kukasiewicz, during the growing seasons of 2012-2015. Aerobiological monitoring, which was based on the volumetric method, was carried out over the 2001-2014 time period. As shown in the study, the flowering period of all the analysed linden taxa lasted 7 weeks, on average, from June 7 to July 24 . The average length of the flowering period of the investigated taxa and hybrids was in the range of 12-17 days. Their flowering periods overlapped. The atmospheric pollen season lasted, on average, from mid-June to the second 10-day period of July. The highest concentration of airborne pollen was noted at the end of June. The pollen season pattern was significantly affected by temperature and relative air humidity as well as by rainfall in May and June. The investigations indicate a 9-day acceleration of the pollen season, which may be associated with global warming.

Keywords: meteorological factors, phenological phases, pollen season, Tilia

\section{INTRODUCTION}

Park and urban alley trees provide Apidae insects with ample rewards in spring and the first half of summer. Under Central European conditions, which includes Poland, most other trees flower mainly during the spring period, whereas the linden flowers in the summer period (Kołtowski, 2006; Lipiński, 2010; Piotrowska-Weryszko \& Weryszko-Chmielewska, 2014). Due to this, lindens can be considered to be one of the last trees to bloom during the growing season in this region of Europe.

The genus Tilia comprises over 60 species growing in the temperate zone of the northern hemisphere (Seneta \& Dolatowski, 2008). These trees reach a height of 20-30(40) $\mathrm{m}$ and live for 300-500 years. In Poland, two wild species occur, i.e. the small-leaved linden (Tilia cordata Mill.) and the broad-leaved linden (T. platyphyllos Scop.). The former grows throughout the country (in the mountains up to an altitude of $600-800 \mathrm{~m}$ a.s.I.). In turn, the latter one is rarely found in the southern lowland belt, Lublin and Małopolska Uplands, Świętokrzyskie Mountains, Lower Silesia, and the Podkarpacie region as well as at lower mountain altitudes (Zając \& Zając, 2001; Mirek et al., 2002). Both species are planted in parks, along roads, and in residential areas. Apart from the native linden species, alien species can be seen in urban greeneries. Lindens are sensitive to drought, soil salinity, 
high temperatures, and air pollution (Bühler, Nielsen, \& Kristoffersen, 2006; Baczewska et al., 2014). Therefore, some species, e.g. native small-leaved and broad-leaved lindens, should not be planted in compact developments, since in such conditions they are infested by pests and lose their leaves early. Hence, alien linden species, which are more resistant to urban conditions, are important for greenery planting. The alien linden species are often characterised by a different flowering period, flower scent, leaf shape and colour, and crown habit (Browicz, 1968; Jones, 1968; Cullen et al., 1984). Some of these species are valuable for beekeeping, given the different periods and abundance of flowering and honey yield (Demianowicz \& Hłyń, 1960; Kołtowski, 2006; Lipiński, 2010). In Poland, over 20 linden taxa are cultivated. By an appropriate choice of alien species, of their hybrids, and of varieties, all flowering at different time points, it is possible to create a beekeeping collection. In combination with native species, the above will provide bees with rewards for over 10 weeks. Such an increased availability of summer rewards often contributes to increased honey yields in apiaries. An increased availability of summer rewards also exerts a beneficial effect on the size of pollen reserves in bee colonies, which determines successful colony development in autumn (Kołtowski, 2006; Lipiński, 2010).

In the liquid state, linden honey is transparent and greenish-yellow. After crystallisation, it becomes light yellow, strongly fragrant, and has a relatively sharp flavour (Waś et al., 2011). The honey yield, depending on the taxon, ranges from 180 to $300 \mathrm{~kg}$ per ha (Lipiński, 2010). But the pollen yield is in the range of $25-90 \mathrm{~kg}$ per 1 ha (Szklanowska \& Teper, 1999; Kołtowski, 2006).

Linden flowers are pentamerous and have numerous stamens and one pistil. Nectar is produced in trichomatous floral nectaries located at the protrusion of the basal part of the sepals (Anderson, 1976; Konarska, 2013; Yousefzadeh et al., 2013). Lindens grown in Poland are characterised by varied abundance of flowering. Approximately 30-year-old individ- uals of T. platyphyllos and T. tomentosa produce, on average, over 200 thousand flowers, $T$. cordata and T. × euchlora over 700 thousand, and $T$. insularis over 1 million (Szklanowska et al., 1999). In comparison with other zoogamous species, lindens produce a great amount of pollen grains, e.g. one T. cordataflower produces, on average, 43500 pollen grains (Szczepanek, 2003). Linden pollen grains are tricolporate, slightly flattened, and medium sized, i.e. 23.7 × 31.0 um (Dyakowska, 1959; Chambers \& Godwin, 1961; Bassett, Crompton, \& Parmelee, 1978). In the flowering period, the linden pollen grains are present in the air, which is confirmed by analyses of the plant pollen concentration in the aeroplankton at different pollen monitoring sites across Poland (Szczepanek, 1994; Stach, Kluza-Wieloch, \& Zientarska, 2006; Piotrowska, 2010; Weryszko-Chmielewska \& Sadowska, 2010; Puc et al., 2015) and in other European countries (Rizzi-Longo et al., 2007; Ščevková et al., 2010). Tilia pollen grains exhibit low allergenic properties (Mur et al., 2001).

Investigation of the variability of phenological phases and pollen seasons is one of the indispensable elements in the development of calendars of flowering and pollen release in melliferous plants. Plant pollen seasons are regarded as indicators of variation in flowering phenology, plant ecology, and climate change (Emberlin et al., 1994, 2002; Menzel et al., 2006). Many authors show that the temperature in the period preceding flowering has a significant effect on the beginning of flowering and pollen release in plants (Primack et al., 2004; Juknys et al., 2011, 2012; Massetti, Petralli, \& Orlandini, 2014). Due to this, the analysis of the dynamics of successive flowering and pollen release stages will allow us to adapt apiary management to the growth of melliferous vegetation and predict in the future, the flowering pattern of plants that are important sources of pollen and nectar (Kołtowski, 2006; Lipiński, 2010).

As confirmed by the results of numerous studies, climate change causes changes in the growth cycle of plants. The results of phenological observations, in particular flowering observations (Chmielewski \& Rötzer, 2001; Primack 
et al., 2004; Czernecki \& Jabłońska, 2016), but also aerobiological observations allow us to determine precisely the beginning and end of pollen release in plants (Frei \& Gassner, 2008; Puc etal., 2015; Zhang et al., 2015). The results of these observations are the strongest biological signal of the existence of such changes. The climate-warming-induced acceleration in flowering time is often associated with the extension of this growth stage. In the case of bee plants, this fact can be significantly important to the development of bee colonies. At a time of progressive climate change, plant growth conditions also change. In the future, new species or varieties better adapted to higher temperatures and lower rainfall may need to be introduced into cultivation (Prażak, 2016). The above situation may also apply to bee plants.

The first aim of the study was to analyse the course of selected phenophases in ten linden taxa. The second aim was to analyse the content of airborne linden pollen grains in Lublin and to determine the relationship between the pollen season parameters and meteorological factors.

\section{MATERIAL AND METHODS}

Phenological phases. The investigations involved 10 taxa of ca. 40-year-old linden trees. Three species were of Asian origin: Tilia amurensis Rupr., which grows naturally in Manchuria and Korea, T. insularis Nakai originates from Korea, and T. japonica (Miq.) from Japan. Three taxa grow in Europe and Asia: T. cordata Mill., T. dasystyla Steven, and T.platyphyllos Scop. Two taxa, T. americana L. and T. michauxii Nutt, are native to North America. Additionally, the $T$. $\times$ euchlora K. Koch ( T. cordata $\times$ T. dasystyla) hybrid, and T. tomentosa Moench 'Petiolaris' were analysed. In total, 16 trees were the objects of the research, including 3 specimens of $T$. cordata, 2 - T. americana, 2 T. insularis, 2 - T. platyphyllos, 2 - T. michauxii, and one specimen of each of the other taxa. The observations of the individual flowering phases were performed on the same specimens during the 2012-2015 time period. To this end, two branches of each experimental tree (one on the south side, the other one on the north side) were selected immediately before the flowering period. Next, the seasonal dynamics of blooming were assessed every day at 14:00-16:00. The phenological observations of flowering biology were carried out using the method described by kukasiewicz (1984). The following phases of generative development were analysed: (P1) appearance of first flowers (several full-blown flowers), (P2) beginning of full bloom (about $25 \%$ of open flowers), (P3) end of full bloom (about $75 \%$ of flowers overblown), and (P4) end of flowering (all flowers overblown). Due to its alternating flowering, T. japonica was not investigated in 2014.

The flowering phenology observations were carried out in the south-western part of Lublin, in the Botanical Garden of the Maria Curie-Skłodowska University in Lublin and its immediate surroundings. The lindens grew in sun-exposed localities on podzolic soil formed on loess and were surrounded by different species of trees and shrubs.

Lublin is located in the central-eastern part of Poland. The climate of the Lublin region is characterised by the influence of continental air masses. The vegetation period in Lublin lasts 215 days (Woś, 1999). The average annual temperature (2001-2014) is $9.1^{\circ} \mathrm{C}$. The average total annual precipitation in Lublin is $546.8 \mathrm{~mm}$ (Department of Meteorology and Climatology, UMCS). West and southwest winds are predominant in the city (Lorenc, 2005).

Pollen season. The content of Tilia pollen in the air of Lublin was analysed from 2001 to 2014 using the volumetric method. A Hirst-type pollen and spore trap (Lanzoni VPPS 2000) was used for pollen sampling using the volumetric method during the Tilia pollen season. The sampler was placed on the roof of a building in the centre of Lublin, on Akademicka Street. The sampler was placed at a height of $18 \mathrm{~m}$ above the ground level (51 ${ }^{\circ} 14^{\prime} 37^{\prime \prime} \mathrm{N}, 22^{\circ} 32^{\prime} 25^{\prime \prime}$ E; $197 \mathrm{~m}$ a.s.l.). Dozens of linden trees grow among compact developments and along the roads in the vicinity of the sampling station. Linden trees are also present in the nearby parks and squares (Kwiatkowski \& Sawicki, 2008). They are also components of 
the forest complexes surrounding Lublin and phytocoenoses located within the city limits (Fijałkowski, 1994). A microscopic analysis of slides was performed and Tilia pollen seasons were determined following the recommendations of the International Association for Aerobiology (Jäger, 2003). Tilia pollen content was estimated in $1 \mathrm{~m}^{3}$ of air per day.

The length of the linden pollen season was calculated with the 98\% method. According to this method, the beginning of the pollen season was defined as the day when $1 \%$ of the cumulative annual pollen sum was recorded, while the day with $99 \%$ of the pollen count recorded was assumed to denote the end of the season (Jäger, 2003). This method allows the exclusion of very low pollen concentrations occurring irregularly and coming from distant transport or from secondary re-deposition (Emberlin et al., 1994; Galan et al., 1995). The following pollen season parameters were analysed: start, end, duration (length of the pollen season), peak value (daily maximum pollen concentration), peak date (date of the daily maximum pollen concentration), and SPI (seasonal pollen index - the sum of pollen grains during the given season). The relationships between individual parameters of the pollen season, phenological phases, and weather factors were determined based on correlation analysis. The distribution of data was tested using the Shapiro-Wilk test. Because the distributions of the data were not normal, Spearman's correlation test was used (Domański, 1990). Statistical analysis was performed using STATISTICA ver. 8 software.

\section{RESULTS}

Phenological phases. On average, the flowering period for all the lindens lasted 7 weeks, from June 7 to July 24 . The sequence of flowering of the individual taxa, i.e. Tilia platyphyllos, T. americana, T. dasystyla, T. cordata, $T$. × euchlora, T. amurensis, T. tomentosa 'Petiolaris', T. japonica, T. michauxii, and T. insularis (Fig. 1), did not change over the study period (Tab. 1). The lindens were characterised by flowering intensity changing from year to year and by relatively alternating flowering. Tilia insularis, T. platyphyllos, and T. tomentosa 'Petiolaris' bloomed fairly regularly every year, while the other taxa exhibited an alternating flowering pattern with greater abundance every second year.

The first bloom dates of T. platyphyllos varied over the study period and were dependent on

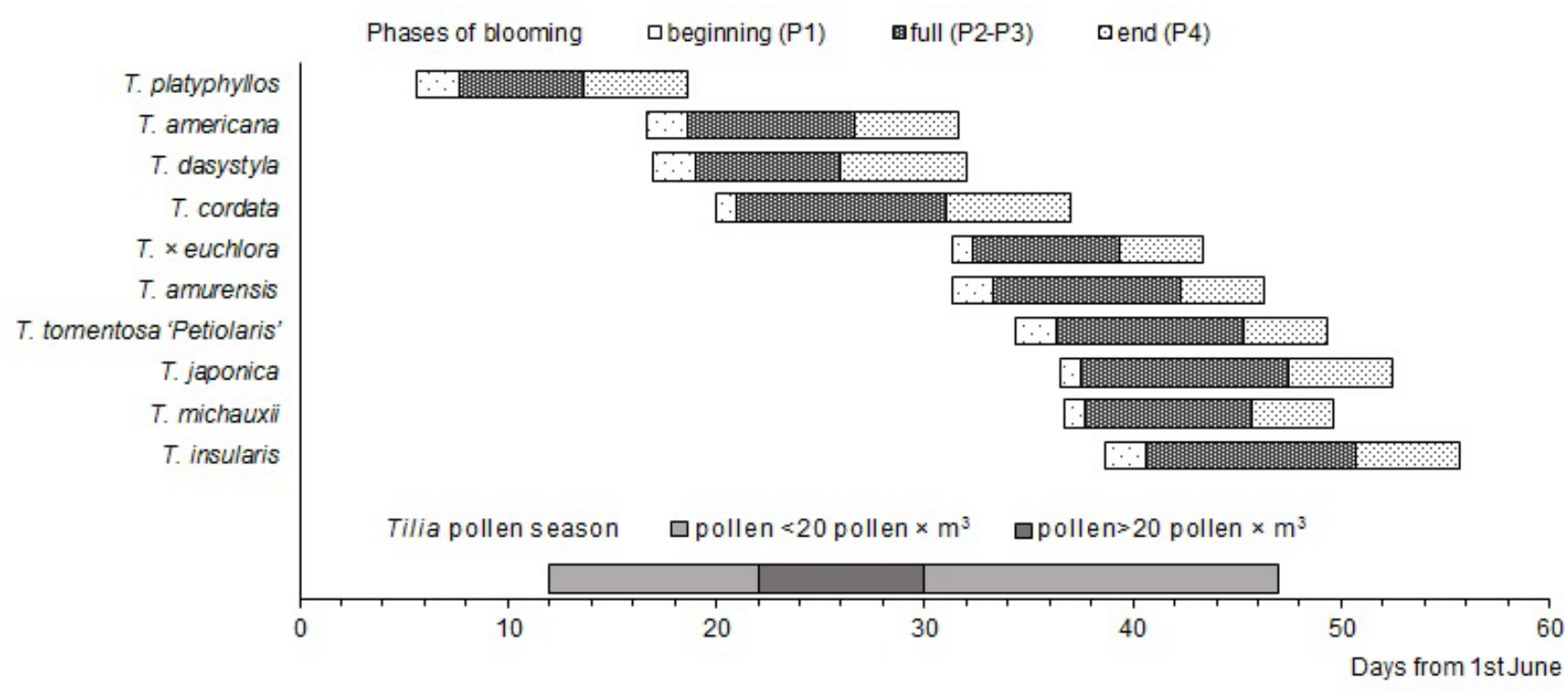

Fig. 1. Time and duration of flowering of Tilia species and Tilia pollen season in the period 2012-2014; phases of blooming: (P1) appearance of first flowers (several full-blown flowers), (P2) beginning of full bloom (about 25\% of open flowers), (P3) end of full bloom (about 75\% of flowers overblown), and (P4) end of flowering (all flowers overblown). 
Table 1

Phenological phases of flowering of the investigated species and hybrids of Tilia in the period 2012-2015

\begin{tabular}{ccccccccccc}
\hline & \multicolumn{10}{c}{ Phenological phases } \\
\cline { 2 - 11 } Takson & \multicolumn{1}{c}{$\begin{array}{c}\text { beginning of } \\
\text { flowering (P1) }\end{array}$} & \multicolumn{2}{c}{$\begin{array}{c}\text { beginning of } \\
\text { full bloom (P2) }\end{array}$} & $\begin{array}{c}\text { end of } \\
\text { full bloom (P3) }\end{array}$ & $\begin{array}{c}\text { end of } \\
\text { flowering (P4) }\end{array}$ & $\begin{array}{c}\text { duration of } \\
\text { flowering (days) }\end{array}$ \\
\cline { 2 - 12 } & Mean \pm SD & CV\% & Mean \pm SD & CV\% & Mean \pm SD & CV\% & Mean \pm SD & CV\% & Mean \pm SD & CV\% \\
\hline T. platyphyllos & $7.06 \pm 2.5$ & 37.0 & $9.06 \pm 2.5$ & 28.6 & $14.06 \pm 3.0$ & 21.7 & $18.06 \pm 3.1$ & 17.0 & $12 \pm 1.3$ & 10.3 \\
T. americana & $18.06 \pm 4.5$ & 24.4 & $20.06 \pm 4.5$ & 22.0 & $27.06 \pm 3.8$ & 13.8 & $2.07 \pm 4.1$ & 12.7 & $15 \pm 0.5$ & 3.4 \\
T. dasystyla & $18.06 \pm 4.2$ & 22.7 & $20.06 \pm 3.7$ & 18.0 & $27.06 \pm 5.0$ & 18.6 & $3.07 \pm 2.9$ & 8.9 & $15 \pm 2.2$ & 14.5 \\
T. cordata & $21.06 \pm 2.9$ & 13.8 & $22.06 \pm 3.4$ & 15.3 & $1.07 \pm 1.8$ & 6.0 & $7.07 \pm 0.5$ & 1.4 & $17 \pm 2.7$ & 16.4 \\
T. x euchlora & $2.07 \pm 1.6$ & 5.1 & $3.07 \pm 2.1$ & 6.2 & $9.07 \pm 1.3$ & 3.2 & $13.07 \pm 1.5$ & 3.5 & $12 \pm 1.0$ & 8.1 \\
T. amurensis & $3.07 \pm 3.6$ & 11.1 & $4.07 \pm 3.2$ & 9.5 & $11.07 \pm 3.1$ & 7.5 & $15.07 \pm 2.4$ & 5.2 & $15 \pm 1.0$ & 6.3 \\
T. tomentosa & $5.07 \pm 1.3$ & 3.6 & $6.07 \pm 1.3$ & 3.5 & $13.07 \pm 1.7$ & 4.0 & $18.07 \pm 1.7$ & 3.6 & $14 \pm 1.6$ & 11.7 \\
'Petiolaris' & & & & & & & & & & \\
T. japonica & $7.07 \pm 1.5$ & 4.1 & $8.07 \pm 1.5$ & 4.0 & $17.07 \pm 1.5$ & 3.3 & $21.07 \pm 1.1$ & 2.3 & $14 \pm 2.1$ & 14.5 \\
T. michauxii & $8.07 \pm 3.7$ & 9.8 & $10.07 \pm 4.9$ & 12.4 & $16.07 \pm 3.4$ & 7.3 & $19.07 \pm 3.1$ & 6.3 & $12 \pm 1.0$ & 7.8 \\
T. insularis & $10.07 \pm 3.7$ & 9.1 & $12.07 \pm 3.9$ & 9.1 & $20.07 \pm 2.2$ & 4.3 & $24.07 \pm 1.7$ & 3.2 & $15 \pm 4.3$ & 28.8 \\
\hline
\end{tabular}

Explanations: (P1) appearance of first flowers (several full-blown flowers); (P2) beginning of full bloom (about 25\% of open flowers); (P3) end of full bloom (about 75\% of flowers overblown); (P4) end of flowering (all flowers overblown). weather conditions. On average, the flowering date was on June 7. The coefficient of variation (CV) for this trait was highest compared to the other species and it was 37\%. Full bloom was observed, on average, on June 9 and the end of full bloom, on average, on June 14. Tilia platyphyllos was characterised by a short flowering period, i.e. 12 days.

Tilia americana and Tilia dasystyla flowered almost simultaneously. The onset of flowering for these taxa was noted during the final phase of $T$. platyphyllos flowering, i.e., on average, on June 18. There were larger differences in the flowering time of these taxa between years compared to the later flowering species - the CV for T. americana and T. dasystyla was $24.4 \%$ and $22.7 \%$, respectively. Full bloom was recorded between June 20 and 27 . The end of flowering was noted between July 2 and 3 . The average length of the flowering period of these taxa was 15 days.

Tilia cordata occurs frequently in the compact developments, parks, and residential areas of Lublin. Tilia cordata usually flowered after June 20. The difference in the dates of the beginning of flowering over the 4 years was 7 days (coefficient of variation $13.8 \%$ ). The end of flowering was noted, on average, on July 7 . The coefficient of variation was only $1.4 \%$. The small-leaved linden exhibited the longest flowering period (17 days), in comparison with the other analysed taxa. The beginning of flowering coincided with the flowering of $T$. americana and $T$. dasystyla, while the end overlapped the flowering period of $T$. $\times$ euchlora, T. amurensis, T. japonica, and T. tomentosa 'Petiolaris' (Tab. 1, Fig. 1).

After the full bloom phase in T. cordata, two other taxa, i.e. T. × euchlora and T. amurensis, began flowering. The onset of their flowering period was noted in the first days of July (the CV for T. $x$ euchlora and T. amurensis was $5.1 \%$ and $11.1 \%$, respectively). Full bloom of both taxa was recorded in the period between July 3 and 11. The flowering period of Tilia $\times$ euchlora was short, i.e. 12 days.

The beginning of Tilia tomentosa 'Petiolaris' flowering was observed, on average, on July 5 , and the end was recorded, on average, on July 18. The difference in the start and end of the flowering of this taxon in the extreme years was only 4 and 5 days, respectively. This taxon was characterised by the most balanced 
flowering pattern during the study years - the coefficient of variation for the analysed phases of flowering was in the range of $3.5-4.0 \%$.

The end of T. cordata flowering was followed by the onset of the flowering period of $T$. japonica and $T$. michauxii (Tab. 1, Fig. 1). The beginning of the flowering of these taxa was noted, on average, on July 7-8 (CV 4.1\%-9.8\%). The end was recorded in the period between July 19 and 21. The full bloom phase in these taxa was observed, on average, between July 8 and 17. Tilia japonica exhibited clear alternation of flowering: it bloomed abundantly in 2013 and 2015 and weakly in 2012. In 2014, it did not produce flowers at all.

Tilia insularis was the last linden taxon to bloom. The species was characterised by abundant and stable flowering every year. The beginning of flowering was recorded, on average, on July 10 (coefficient of variation 9.1\%), while the end was always recorded in the third 10 days of July (on average, on July 24).

Pollen season. In mid-June, linden pollen appeared in the air of Lublin. The graphic image of the pollen season clearly had one peak - with the highest pollen concentration in late June and in July (Fig. 2).

Over the study period analysed, the difference in the onset of the linden pollen season in the extreme years was more than 2 weeks (Tab. 2). The earliest start of the Tilia pollen season was noted in 2007 (June 8) and the latest in 2004 (June 24). The earliest end of the pollen season was recorded in 2002 (July 2) and the latest in 2006 (July 26). The significance of this variability is evidenced by the value of the coefficient of variation, i.e. $35.0 \%$ for the beginning and end of the season (Tab. 2). The length of the pollen season exhibited the lowest variability and differed by 24 days in the extreme years of the study. The average length of the season was 35 days. The highest variability was found for the maximum concentration of linden pollen, with a variation coefficient of $62 \%$, while the annual seasonal pollen index (SPI) was characterised by a coefficient of variation of $56 \%$ (Tab. 2). The seasonal peak, usually recorded at the end of June, was preceded by a 1.5-week period of low pollen concentrations. There was a 1-month difference in the occurrence date of the maximum pollen concentrations in the extreme years. During the 14-year study period, the highest value of maximum daily concentration, i.e. $97 \mathrm{P} / \mathrm{m}^{3}$, was recorded in 2006, while the lowest maximum value observed in 2014 was merely $9 \mathrm{P} / \mathrm{m}^{3}$. The annual sum of linden

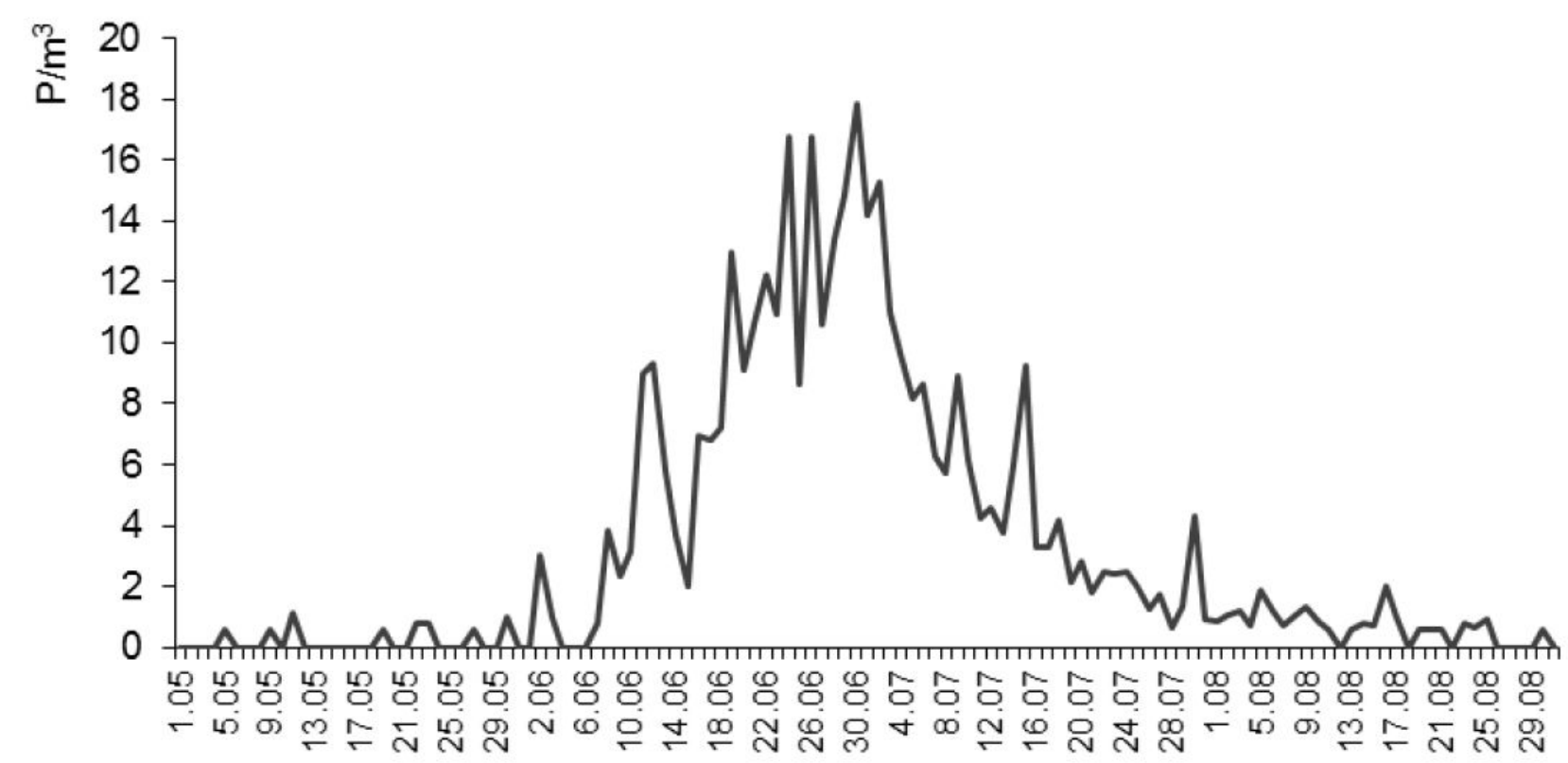

Fig. 2. Tilia pollen concentrations in the atmosphere of Lublin (average for 2001-2014). 
Table 2

Statistics of the parameters of the Tilia pollen season in Lublin in the period 2001-2014

\begin{tabular}{ccccccc}
\hline \multirow{2}{*}{ Statistics } & \multicolumn{3}{c}{ Pollen season } & \multicolumn{3}{c}{ Peak } \\
\cline { 2 - 7 } & start & end & $\begin{array}{c}\text { duration } \\
\text { (days) }\end{array}$ & $\begin{array}{c}\text { value } \\
\left(\mathrm{P} / \mathrm{m}^{3}\right)\end{array}$ & date & $\begin{array}{c}\text { SPI } \\
\text { (pollen sum) }\end{array}$ \\
\hline Mean \pm SD & $14.06 \pm 5.0$ & $18.07 \pm 6.5$ & $35.0 \pm 6.5$ & $42.0 \pm 26.1$ & $26.06 \pm 8.1$ & $283.0 \pm 159.0$ \\
Min - max & $8.06-24.06$ & $2.07-26.07$ & $21.0-45.0$ & $9.0-97.0$ & $10.06-9.07$ & $79.0-624.0$ \\
CV\% & 35.0 & 35.0 & 19.0 & 62.0 & 31.0 & 56.0 \\
\hline
\end{tabular}

pollen was characterised by a relatively high dispersion of values (an 8-fold difference).

The seasonal pollen index analysis showed the highest values of the annual pollen sums to be in the middle and at the end of the 2001-2014 period, although no significant trend was found (Fig. 3).

The statistical analysis revealed statistically insignificant trends at the onset of the Tilia pollen season and the date of maximum pollen concentration, which indicated 9-day acceleration of the linden pollen season over the 14-year study period (Fig. 4).

Spearman's $r$ correlation analysis showed a positive correlation between the onset of the linden pollen season and the maximum concentration date (Tab. 3). This implies that in the case of a late onset of the linden pollen season, the maximum concentration will be observed later as well. A relatively high level of a significant positive correlation was found between the end of the linden pollen season and the duration, peak value, peak date, and SPI. Furthermore, there was a significant effect of season length on the value of the maximum daily concentration and the annual sum of linden pollen (SPI). In shorter pollen seasons, the peak value and SPI were lower. The highest positive correlation was observed between the peak value and SPI (Tab. 3).

\section{Correlation between phenological phases and pollen season}

The linden flowering period in Lublin in the 2012-2014 time period, started, on average, on June 6 and lasted until July 25. During this period, the Tilia pollen season started, on average, on June 12 and ended on July 17 (Fig. 1).

Spearman's r correlation analysis showed that the analysed parameters of the Tilia pollen season were significantly correlated with the flowering phenophases of four linden taxa; T. cordata, T. × euchlora, T. amurensis, and T. tomentosa 'Petiolaris' (Tab. 4).

The statistical analysis revealed that an early

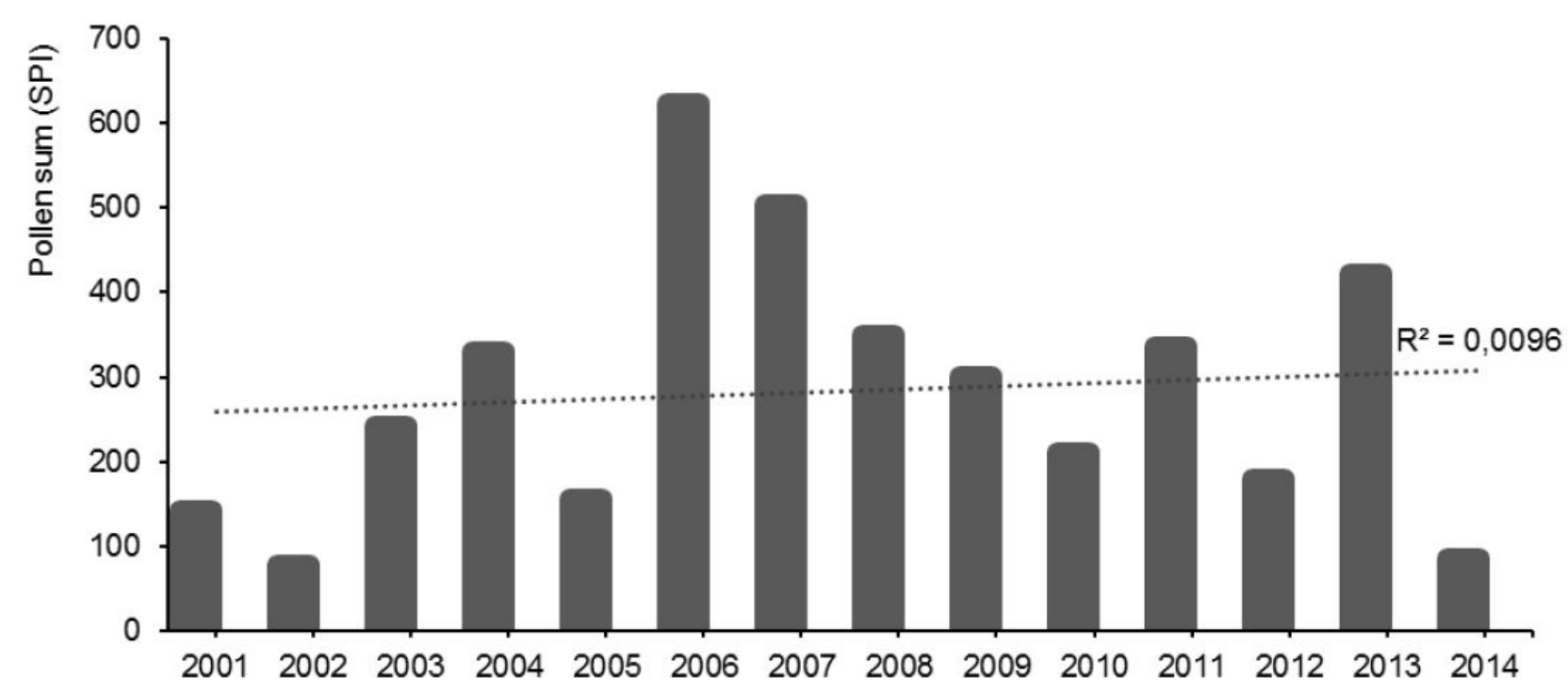

Fig. 3. The linear trend of Tilia pollen sums during the pollen seasons in Lublin, 2001-2014. 
Table 3

Spearman's correlations between the parameters of the Tilia pollen season in Lublin in the period 2001-2014

\begin{tabular}{cc}
\hline Parameters of pollen season & Spearman coefficient \\
\hline Start \& peak date & $0.762^{\star \star}$ \\
End \& duration & $0.703^{\star \star}$ \\
End \& peak value & $0.664^{\star}$ \\
End \& peak date & $0.724^{\star \star}$ \\
End \& SPI & $0.706^{\star \star}$ \\
Duration \& peak value & $0.572^{\star}$ \\
Duration \& SPI & $0.588^{\star}$ \\
Peak value \& SPI & $0.964^{\star \star}$ \\
\hline
\end{tabular}

Level of significance * $-0.05,{ }^{\star \star}-0.01$; SPI - seasonal pollen index (the sum of pollen grains during the given season).

Table 4

Significant Spearman's correlations between phenological phases and Tilia pollen season parameters in Lublin in the period 2001-2014

\begin{tabular}{ccc}
\hline Tilia species & $\begin{array}{c}\text { Phenological phases \& parameters of } \\
\text { pollen season }\end{array}$ & Spearman coefficient \\
\hline \multirow{3}{*}{ T. cordata } & Beginning of flowering (P1) \& end & $-0.875^{\star \star}$ \\
& Beginning of full bloom (P2) \& end & $-0.891^{\star \star}$ \\
& End of full bloom (P3) \& peak date & $-0.741^{\star \star}$ \\
& Duration of flowering \& end & $0.912^{\star \star}$ \\
\hline \multirow{2}{*}{ T. × euchlora } & Beginning of flowering (P1) \& end & $0.833^{\star \star}$ \\
& Duration of flowering \& end & $-0.745^{\star \star}$ \\
\hline \multirow{2}{*}{ T. amurensis } & Beginning of full bloom (P2) \& end & $0.643^{\star}$ \\
\hline T. tomentosa & Beginning of full bloom (P2) \& duration & $0.664^{\star}$ \\
'Petiolaris' & Beginning of flowering (P1) \& end & $0.720^{\star \star}$ \\
\hline
\end{tabular}

Level of significance * $-0.05,{ }^{* \star}-0.01$. 


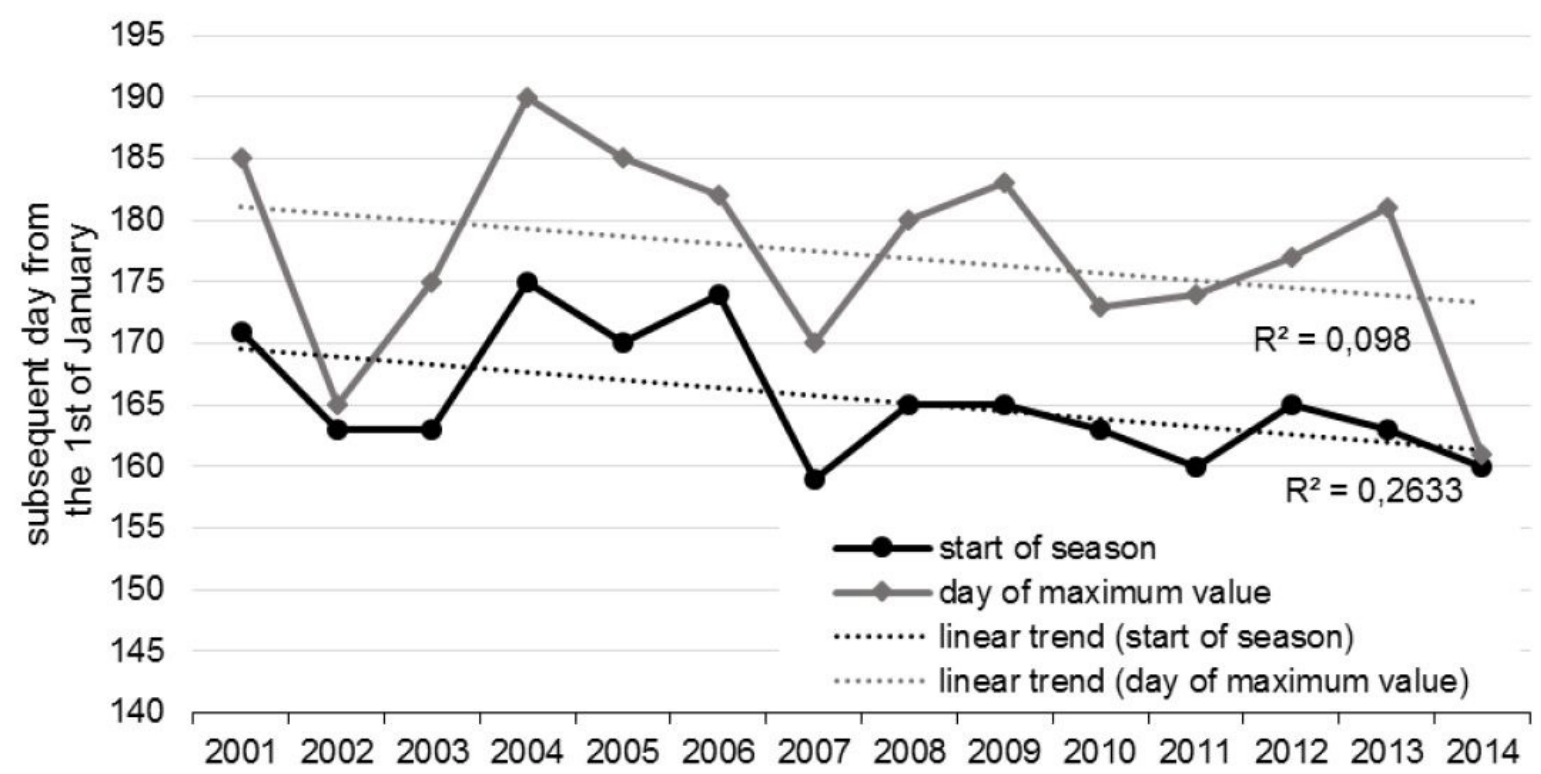

Fig. 4. Linear trends of selected features of Tilia pollen seasons in Lublin, 2001-2014.

flowering of $T$. cordata significantly increased the duration of the pollen season. The analysis also revealed that the maximum concentration of Tilia pollen in the air was recorded during the full bloom stage of this species.

Similarly, the date of the onset and full bloom of three other taxa, i.e. T. × euchlora, T. amurensis, and T. tomentosa 'Petiolaris', had a significant effect on the end and duration of the pollen season (Tab. 4). This indicates that pollen grains of alien linden taxa and hybrids significantly increase the duration of the pollen season.

Correlation between the pollen season and meteorological factors

Spearman's r correlation analysis showed that the Tilia pollen season started earlier when the air temperature in May and June were high, and the precipitation rates in the first 10 days of June were lower than in the next 10-day periods (Tab. 5). The end date of the pollen season was influenced by air temperature in May, and air humidity in June. Lower temperatures in May, and higher humidity in May and June, contributed to a longer duration of the linden pollen season. The seasonal maximum value was positively correlated with the temperature in June, which implies that the highest peak values were recorded in a period characterised by higher temperatures. The high air humidity in the second 10 days of
June contributed to a decrease in the values of maximum pollen concentrations. The date of the maximum pollen concentration in the air was significantly correlated with the temperature and precipitation in May and June. The higher temperatures at the end of June increased the SPI values. On the other hand, the higher air humidity in June reduced the SPI value (Tab. 5).

\section{DISCUSSION}

The flowering of lindens occurs during an important period in the development of bee colonies. This period is called the main reward period and in Poland usually lasts from June to the second 10-day period of July. During this time, many other species that produce nectar in abundance also bloom, among others; black locust, oilseed rape, clover, and buckwheat (Prabucki, 1998; Lipiński, 2010). In this period, the work of a bee colony is mainly concentrated on the collection of nectar and its transport to the hive, the conversion of nectar into honey, and the accumulation of honey reserves. Numerous foragers participate in nectar collection, but young bees aged only 14 days also take part. The development of bee larvae, which require constant feeding, also takes place during this period. The strength of a bee 
Table 5

Spearman's correlations between Tilia pollen season parameters and meteorological factors in Lublin in the period 2001-2014

\begin{tabular}{|c|c|c|}
\hline \multicolumn{2}{|r|}{ Season parameter vs meteorological factor } & Spearman coefficient \\
\hline \multirow{8}{*}{$\begin{array}{c}\text { Dependent variable: } \\
\text { season start }\end{array}$} & mean temperature in the second 10-day period of May & $-0.621^{\star}$ \\
\hline & mean temperature in the third 10-day period of May & $-0.729 * *$ \\
\hline & maximum temperature in the third 10-day period of May & $-0.685^{\star}$ \\
\hline & minimum temperature in the third 10-day period of May & $-0.760 * \star$ \\
\hline & mean temperature in the first 10-day period of June & $-0.728^{\star \star}$ \\
\hline & maximum temperature in the first 10-day period of June & $-0.693^{\star}$ \\
\hline & minimum temperature in the first 10 -day period of June & $-0.855^{\star \star}$ \\
\hline & rainfall in the first 10-day period of June & $0.628^{\star}$ \\
\hline \multirow{6}{*}{$\begin{array}{l}\text { Dependent variable: } \\
\text { season end }\end{array}$} & mean temperature in May & $-0.698^{\star \star}$ \\
\hline & maximum temperature in May & $-0.642^{\star}$ \\
\hline & minimum temperature in May & $-0.676^{\star}$ \\
\hline & rainfall in the first 10-day period of June & $0.722^{* *}$ \\
\hline & humidity in the first 10-day period of June & $0.740^{\star \star}$ \\
\hline & humidity in June & $0.778^{\star \star}$ \\
\hline \multirow{6}{*}{$\begin{array}{c}\text { Dependent variable: } \\
\text { duration }\end{array}$} & mean temperature in the first 10-day period of May & $-0.650^{\star}$ \\
\hline & maximum temperature in the first 10-day period of May & $-0.635^{\star}$ \\
\hline & minimum temperature in the first 10-day period of May & $-0.660^{*}$ \\
\hline & humidity in the first 10-day period of May & $0.744^{\star \star}$ \\
\hline & humidity in May & $0.765^{\star \star}$ \\
\hline & humidity in the third 10-day period of June & $0.789^{\star *}$ \\
\hline \multirow{3}{*}{$\begin{array}{l}\text { Dependent variable: } \\
\text { peak value }\end{array}$} & mean temperature in the first 10-day period of June & $0.624^{\star}$ \\
\hline & maximum temperature in the third 10-day period of June & $0.627 *$ \\
\hline & humidity in the second 10 -day period of June & $-0.912^{\star *}$ \\
\hline \multirow{14}{*}{$\begin{array}{l}\text { Dependent variable: } \\
\text { peak date }\end{array}$} & mean temperature in the second 10-day period of May & $-0.795^{\star \star}$ \\
\hline & maximum temperature in the second 10 -day period of May & $-0.751^{\star \star}$ \\
\hline & minimum temperature in the second 10 -day period of May & $-0.804^{\star *}$ \\
\hline & mean temperature in the third 10-day period of May & $-0.667^{\star}$ \\
\hline & minimum temperature in the third 10-day period of May & $-0.809 \star \star$ \\
\hline & mean temperature in May & $-0.842^{\star \star}$ \\
\hline & maximum temperature in May & $-0.774^{\star \star}$ \\
\hline & minimum temperature in May & $-0.859 * *$ \\
\hline & minimum temperature in the first 10-day period of June & $-0.650^{*}$ \\
\hline & mean temperature in the second 10-day period of June & $-0.685^{\star}$ \\
\hline & maximum temperature in the second 10 -day period of June & $-0.663^{\star}$ \\
\hline & minimum temperature in the second 10 -day period of June & $-0.788^{\star \star}$ \\
\hline & rainfall in the third 10-day period of May & $0.665^{\star}$ \\
\hline & rainfall in the first 10-day period of June & $0.632^{*}$ \\
\hline \multirow{3}{*}{$\begin{array}{l}\text { Dependent variable: } \\
\qquad \text { SPI }\end{array}$} & maximum temperature in the third 10-day period of June & $0.631^{*}$ \\
\hline & humidity in the second 10-day period of June & $-0.916^{\star \star}$ \\
\hline & humidity in June & $-0.687^{\star}$ \\
\hline
\end{tabular}

Level of significance * $0.05,{ }^{* *}-0.01$; SPI - seasonal pollen index (the sum of pollen grains during the given season). 
colony is dependent on the abundance of nectar sources (Prabucki, 1998).

Phenological observations carried out in various cities in Poland show that the variation range of linden flowering onset dates may even be two weeks. The observations of Stach et al. (2006) and Pawlikowski (2010) reveal that in western Poland the small-leaved linden blooms, on average, on June 13, i.e. 8 days earlier compared to the results found in Lublin (June 21). On the other hand, the long-term phenological observations of Lipiński (2010) demonstrate that in the central-eastern part of Poland T. cordatablooms, on average, on June 26, which is 5 days later than in Lublin. The variation in the occurrence of the small-leaved linden's particular flowering phases is smaller for the nearby cities, as confirmed by the previous studies conducted by WeryszkoChmielewska and Sadowska (2010) in Lublin, Szklanowska et al. (1999) as well as Jabłoński and Kołtowski (1999) in Puławy, and Czubacki (1996) in Zamość. On average, the beginning of the flowering of the small-leaved linden in the above-mentioned cities located in the centraleastern part of Poland, is on June 21.

Due to climate warming, the main reward period can begin earlier. This is shown by the results of our phenological and aerobiological investigations which reveal that the pollen release period of linden accelerated by 9 days over the 14-year period. The results of other authors' studies also indicate an acceleration in the flowering period of many herbaceous and tree species over the last few decades (Emberlin, 2002; Menzel et al., 2006; Puc et al., 2015).

The observations carried out in Lublin concerning the flowering dates of alien linden species and hybrids as well as the duration of the flowering periods and the differences in flowering seasons between the study years, agree with the results reported by Szklanowska et al. (1999), Jabłoński and Kołtowski (1999) from Puławy, Lipiński (2010) from Warsaw, Demianowicz and Hłyń (1960) from Kórnik, and Pawlikowski (2010) from Toruń. Based on phenological observations carried out in different regions of Poland, it has been found that Tilia americana starts flowering the earliest of the most frequently cultivated alien linden species, and is followed by $T$. dasystyla, T. × euchlora, T.amurensis, T. tomentosa'Petiolaris', T.japonica, and $T$. insularis. Their flowering periods last, on average, 2 weeks. The greatest difference in the flowering date between years is one week. The sequence of flowering of these taxa in Poland follows a latitudinal direction, i.e. from the south northwards. The start of the flowering period of Tilia $\times$ euchlora, T. tomentosa, T. japonica, and T. insularis was recorded in the first 10 days of July in Lublin and Puławy, and in the second 10 days of July in the west and north of Poland.

Alternate flowering reported for the majority of the investigated species is in agreement with the observations described by other authors (Demianowicz \& Hłyń, 1960; Jabłoński \& Kołtowski, 1999; Szklanowska et al., 1999; Lipiński, 2010). Regular yearly flowering of some taxa (T. insularis, T. platyphyllos, and T.tomentosa 'Petiolaris') and alternate biennial flowering of the other ones ( $T$. americana, T.amurensis, T. cordata, T. dasystyla, T. × euchlora, T. japonica, and $T$. michauxii), can be regarded as a biological feature of these taxa.

In Poland, linden pollen is present in the aeroplankton from mid-june to the end of July (Szczepanek, 1994; Stach, Kluza-Wieloch, \& Zientarska, 2006; Piotrowska, 2010; WeryszkoChmielewska \& Sadowska, 2010), which was also confirmed in Lublin. The highest pollen concentration was recorded at the end of June and, less frequently, at the beginning of July. A similar regularity was observed in Bratislava, Slovakia (Ščevková et al., 2010). Linden sporomorphs were recorded in mid-May in Triest, north-eastern Italy (Rizzi-Longo et al., 2007), and in the second 10-day period of July in Skien, southwestern Norway (Piotrowska, 2010).

The linden pollen seasons in various cities of Poland and in other European countries are characterised by low annual totals. This is primarily associated with the fact that the linden is an entomophilous plant and has large, heavy pollen grains with a high falling rate (Dyakowska, 1959). In this case, the distance between the sampling site and blooming specimens is of great importance. The seasonal pollen index 
(SPI) in Lublin was over three-fold higher than that in other cities in Poland and in other European countries (Szczepanek, 1994; Stach, Kluza-Wieloch, \& Zientarska, 2006; Rizzi-Longo et al., 2007; Piotrowska, 2010; Ščevková et al., 2010). The difference may be related to the fact that lindens are very common in Lublin's urban greenery.

The flowering of all the studied linden species lasted a total of 48 days, on average, from June 7 to July 24. In the case of the earliest flowering species, i.e. Tilia platyphyllos, T. americana and $T$. dasystyla, there were distinctly greater differences in the flowering time between years, which averaged 8 days, compared to the linden species that flower later (in July) in the case of which the variation in flowering time was, on average, 6 days. The flowering period of the specific species or hybrids lasted about two weeks. The overlapping of their flowering periods proved to be strong, while it was weaker in the case of $T$. platyphyllos. The selected linden species and hybrids that are presented in this paper can provide the honey bee and wild Apidae insects uninterrupted pollen and nectar rewards, on average, from June 7 to July 24. This study shows a trend towards acceleration (by 9 days) of the pollen season noted over a period of 14 years. Such a trend may be associated with global warming. The atmospheric pollen season lasted, on average, from mid-June to the second 10-day period of July. The highest concentration of airborne pollen was found at the end of June. The onset of linden pollen seasons, their duration as well as maximum pollen concentrations and annual pollen totals (SPI), were dependent on temperature and relative air humidity as well as on rainfall in May and June.

\section{ACKNOWLEDGEMENTS}

This research was supported financially by the Polish Ministry of Science and Higher Education as a part of the statutory activities of the Botanical Garden, Maria Curie-Skłodowska University, the Department of General Ecology and the Department of Botany, University of Life Sciences, Lublin.

\section{REFERENCES}

Anderson, G. J. (1976). The pollination biology of Tilia. American Journal of Botany, 63(9), 12031212. http://doi.org/10.2307/2441737

Baczewska, A. H., Dmuchowski, W., Jozwiak, A., Gozdowski, D., Brągoszewska, P., Dąbrowski, P., Swiezewska, E. (2014). Effect of salt stress on prenol lipids in the leaves of Tilia 'Euchlora'. Dendrobiology, 72, 177-186. http://doi.org/10.12657/denbio.072.015

Bassett, J., Crompton, C. W., \& Parmelee, J. A. (1978). An atlas airborne pollen grains and common fungus spores of Canada. Ottawa. Ontario: Biosystematics Research Institute.

Browicz, K. (1968). Tilia L. In Flora Europaea 2. Rosaceae to Umbelliferae. (pp. 247-248). Cambridge: Cambridge University Press.

Bühler, O., Nielsen, Ch. N., \& Kristoffersen, P. (2006). Growth and phenology of established Tilia cordata street trees in response to different irrigation regimes. Arboriculture \& Urban Forestry, 32(1), 3-9.

Chambers, T. C., \& Godwin, H. (1961). The fine structure of the pollen wall of Tilia platyphy/los. New Phytologist, 6033), 393-399. http://doi. org/10.1111/j.1469-8137.1961.tb06263.x

Chmielewski, F. M., \& Rötzer, T. (2001). Response of tree phenology to climate change across Europe. Agricultural and Forest Meteorology, 108, 101-112. http://doi.org/10.1016/S0168-1923(01)00233-7

Cullen, J., Alexander, J. C. M., Brickell, C. D., Edmondson, J. R., Green, P. S., Heywood, P. M., ...Yeo, P. F. (1984). The European Garden Flora 5. Dicotyledones 3. A manual for the identification of plants cultivated in Europe, both out-of-doors and under glass. Cambridge: Cambridge University Press.

Czernecki, B., \& Jabłońska, K. (2016). Reconstruction of late spring phenophases in Poland and their response to climate change, 1951-2014. Acta Agrobotanica, 65(2), 1671. http://doi.org/10.5586/aa.1671 
Czubacki, W. (1996). Niektóre szczegóły biologii kwitnienia i nektarowania lip ( Tilia platyphyllos Scop. i Tilia cordata Mill.). Pszczelnicze Zeszyty Naukowe, 401), 15-26.

Demianowicz, Z., \& Hłyń, M. (1960). Porównawcze badania nad nektarowaniem 17 gatunków lip. Pszczelnicze Zeszyty Naukowe, 4(3-4), 133-152.

Domański, C. (1990). Testy statystyczne. Warszawa: Państwowe Wydawnictwa Ekonomiczne.

Dyakowska, J. (1959). Podręcznik palynologiï. Metody i problemy. Warszawa: Państwowe Wydawnictwa Geologiczne.

Emberlin, J., Detandt, M., Gehrig, R., Jaeger, S., Nolard, N., Rantio-Lehtimäki, A. (2002). Responses in the start of Betula (birch) pollen seasons to recent changes in spring temperatures across. International Journal of Biometeorology, 46, 159-170.

Emberlin, J., Jones, S., Bailey, J., Caulton, E., Corden, J., Dubbels, S., ... Spencer, T. (1994). Variation in the start of the grass pollen season at selected sites in the United Kingdom 1987-1992. Grana, 33, 94-99. http://doi.org/10.1080/00173139409427839

Fijałkowski, D. (1994). Flora roślin naczyniowych Lubelszczyzny 2. Lublin: Lubelskie Towarzystwo Naukowe.

Frei, T., \& Gassner, E. (2008). Climate change and its impact on birch pollen quantities and the start of the pollen season an example from Switzerland for the period 1969-2006. International Journal of Biometeorology, 52, 667-674. http://doi.org/10.1007/ s00484-008-0159-2

Galan, C., Emberlin, J., Dominguez, E., Bryant, R. H., Villamandos, F. (1995). A comparative analysis of daily variations in the Gramineae pollen counts at Córdoba, Spain and London, UK. Grana, 34, 189-198. http:// doi.org/10.1080/00173139509429042

Jabłoński, B., \& Kołtowski, Z. (1999). Nektarowanie różnych gatunków i mieszańców lipy (Tilia L.). Pszczelnicze Zeszyty Naukowe, 43(1), 279-290.
Jäger, S. (2003). The European Pollen Information System (epi). Data bank (EAN), Web sites and forecasting. Advances in Dermatology and Allergology, 20(4), 239-243.

Jones, G. N. (1968). Taxonomy of the American species of linden (Tilia). Illinois Biological Monographs 39. Urbana: University of Illinois Press.

Juknys, R., Sujetovienè, G., Žeimavičius, K., Gustainyte, J. (2011). Effects of climate warming on timing of lime ( Tilia cordataL.) phenology. Environmental Engineering, 1, 139-143.

Juknys, R., Sujetovienè, G., Žeimavičius, K., Šveikauskaitè, I. (2012). Comparison of climate warming induced changes in silver birch (Betula pendula Roth) and lime ( Tilia cordata Mill.) phenology. Baltic Forest$r y, 78(1), 25-32$

Konarska, A. (2013). Preliminary studies on the structure of sepals and trichomatous nectaries in flowers of Tilia cordata Mill. Acta Scientiarum Polonorum, Hortorum Cultus, 12(2), 63-74.

Kołtowski, Z. (2006). Wielki atlas roślin miododajnych. Zielne rośliny pożytkowe. Drzewa i krzewy pożytkowe. Warszawa: Przedsiębiorstwo Wydawnicze Rzeczpospolita SA.

Kwiatkowski, M., \& Sawicki, R. (2008). Najstarsze drzewa w Ogrodzie Botanicznym UMCS w Lublinie. Biuletyn Ogrodów Botanicznych, 17,29-30.

Lipiński, M. (2010). Pożytki pszczele. Zapylenie i miododajność roślin. Warszawa: Powszechne Wydawnictwo Rolnicze i Leśne, Stróże: Wydawnictwo Sądecki Bartnik.

Lorenc, H. (2005). Atlas Klimatu Polski. Warszawa: Instytut Meteorologii i Gospodarki Wodnej.

Łukasiewicz, A. (1984). Potrzeba ujednolicenia metodyki fenologicznej w polskich ogrodach botanicznych i arboretach. Wiadomości Botaniczne, 28(2), 153-158.

Massetti, L., Petralli, M., \& Orlandini, S. (2014). The ef- 


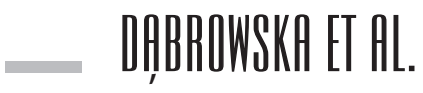

fect of urban morphology on Tiliaxeuropaea flowering. Urban Forestry \& Urban Greening, 14(1), 187193. http://doi.org/10.1016/j.ufug.2014.10.005

Menzel, A., Sparks, T. H., Estrella, N., Koch, E., Aasa, A., Ahas, R.,... Zust, A. (2006). European phonological response to climate change matches the warming pattern. Global Change Biology, 12, 1969-1976. http://doi.org/10.1111/j.1365-2486.2006.01193.x

Mirek, Z., Piękoś-Mirkowa, H., Zając, A., Zając, M. (2002). Flowering plants and pteridophytes of Poland - a checklist. In Biodiversity of Poland T. (pp. 177). Kraków: W. Szafer Institute of Botany, Polish Academy of Sciences.

Mur, P., FeoBrito, F., Lombardero, M., Barber, D., Galindo, P. A., Gomez, E., Borja, J. (2001). Allergy to linden pollen (Tilia cordata). Allergy, 56, 457-458. http://doi. org/10.1034/j.1398-9995.2001.056005457.x

Pawlikowski, T. (2010). Pollination activity of bees (Apoidea: Apiformes) visiting the flowers of Tilia cordata Mill. and Tilia tomentosa Moench in the urban environment. Journal of Apicultural Science, 54(2), 73-79.

Piotrowska, K. (2010). Variations in pollen deposition of some plant taxa in Lublin (Poland) and in Skien (Norway). Acta Agrobotanica, 63(1), 37-46. http:/l doi.org/10.5586/aa.2010.005

Piotrowska-Weryszko, K., \& Weryszko-Chmielewska, E. (2014). The airborne pollen calendar for Lublin, central-eastern Poland. Annals of Agricultural and Environmental Medicine, 27(3), 541-545.

Prabucki, J. (1998). Pszczelnictwo. Szczecin: Wydawnictwo Promocyjne Albatros.

Prażak, R. (2016). Prospects for Sorghumcultivation in Poland. Acta Agrobotanica, 69(2), 1661. http://doi. org/10.5586/aa.1661

Primack, D., Imbres, C., Primack, R. B., Miller-Rushing, A. J., Del Tredici, P. (2004). Herbarium speci-mens demonstrate earlier flowering times in response to warming in Boston. American Journal of Botany, 97,
1260-1264. http://doi.org/10.3732/ajb.91.8.126012

Puc, M., Wolski, T., Camacho, I. C., Myszkowska, D., Kasprzyk, l., Grewling, Ł., ... Borycka, K. (2015). Fluctuation of birch (Betula L.) pollen seasons in Poland. Acta Agrobotanica, 68(4), 303-313. http://doi. org/10.5586/aa.2015.041

Rizzi-Longo, L., Pizzulin-Sauli, M., Stravisi, F., Ganis, P. (2007). Airborne pollen calendar for Trieste (Italy), 1990-2004. Grana, 46(2), 98-109. http://doi. org/10.1080/00173130701302826

Seneta, W., \& Dolatowski,.. (2008). Dendrologia. Warszawa: Wydawnictwo Naukowe PWN.

Stach, A., Kluza-Wieloch, M., \& Zientarska, A. (2006). The phenology of flowering and fluctuations of airborne pollen concentrations of selected trees in Poznań, 2003-2004. Acta Agrobotanica, 59(1), 301308. http://doi.org/10.5586/aa.2006.031

Szczepanek, K. (1994). Pollen calendar for Cracow (southern Poland), 1982-1991. Aerobiologia, 17, 6570.

Szczepanek, K. (2003). Wytwarzanie i rozprzestrzenianie spor i ziaren pyłku. In Palinologia. (pp. 16-28). Kraków: Instytut Botaniki im. W. Szafera, PAN.

Szklanowska, K., \& Teper, D. (1999). Wydajność pyłkowa różnych gatunków i mieszańców lipy (Tilia L.). Pszczelnicze Zeszyty Naukowe, 43(1), 291-301.

Szklanowska, K., Teper, D., Jablonski, B., Kołtowski, Z. (1999). Wybrane zjawiska biologii kwitnienia różnych gatunków i mieszańców lipy (Tilia L.) oraz oblotu ich przez pszczoły. Pszczelnicze Zeszyty Naukowe, $43(1), 263-278$

Ščevková, J., Dušička, J., Chrenová, J., Mičieta, K. (2010). Annual pollen spectrum variations in the air of Bratislava (Slovakia): years 2002-2009. Aerobiologia, 26, 277-287. http://doi.org/10.1007/s10453-010-9163-1

Waś, E., Rybak-Chmielewska, H., Szczęsna, T., Kachaniuk, K., Teper, D. (2011). Characteristics of Polish unifloral honeys. II. Lime honey (Tilia spp.). Journal of 
Apicultural Science, 55(1), 121-129.

Weryszko-Chmielewska, E., \& Sadowska, D. (2010). The phenology of flowering and pollen release in four species of Linden ( Tilia L.). Journal of Apicultural Science, 54(2), 99-108.

Woś, A. (1999). Klimat Polski. Warszawa: Wydawnictwo Naukowe PWN.

Yousefzadeh, H., Tabari, M., Hosseinzadeh, Colagar, A., Sattarian, A., Assadi, M. (2013). Flower and pollen morphology variations in Tilia spp. populations in hyrcanain forests. Journal of Forest and Wood Products, 65(4), 497-508.

Zając, A., \& Zając, M. (2001). Distribution atlas of vascular plants in Poland. Kraków: Pracownia Chorologii Komputerowej Instytut Botaniki UJ.

Zhang, Y., Bielory, L., Mi, Z., Cai, T., Robock, A., Georgopoulos, P. (2015). Allergenic pollen season variations in the past two decades under changing climate in the United States. Global Change Biology, 27(4), 1581-1589. http://doi.org/10.1111/gcb.12755 
